\title{
An Overview of the Current Hepatitis B Treatment Strategies after Liver Transplantation
}

Arash Dooghaie Moghadam ${ }^{1}$, Pegah Eslami ${ }^{2}$, Amirreza Dowlati Beirami ${ }^{3}$, Shahrokh Iravani ${ }^{4}$, Ermia Farokhi ${ }^{5}$,Alireza Mansour-Ghanaei ${ }^{6}$, Mahmood Reza Hashemi $^{7}$, MortezaAghajanpoor Pasha ${ }^{8}$, Azim Mehrvar $^{9}$, Mohssen Nassiri-Toosi ${ }^{10, *}$

1. Research Institute for Gastroenterology and Liver Diseases, Shahid Beheshti University of Medical Sciences, Tehran, Iran

2. Research Institute for Gastroenterology and Liver Diseases, Shahid Beheshti University of Medical Sciences, Tehran, Iran

3. Research Institute for Gastroenterology and Liver Diseases, Shahid Beheshti University of Medical Sciences, Tehran, Iran

4. Research Center for Cancer Screening and Epidemiology, AJA University of Medical Sciences, Tehran, Iran

5. Liver Transplantation Research Center, Tehran University of Medical Sciences, Tehran, Iran

6. Gastrointestinal and Liver Diseases Research Center (GLDRC), Guilan University of Medical Sciences, Guilan, Iran

7. Gastroenterology and Hepatobiliary Research Center, AJA University of Medical Sciences, Tehran, Iran

8. Gastroenterology and Hepatobiliary Research Center, AJA University of Medical Sciences, Tehran, Iran

9. Research Center for Cancer Screening and Epidemiology, AJA University of Medical Sciences, Tehran, Iran

10. Liver Transplantation Research Center, Tehran University of Medical Sciences, Tehran, Iran

\footnotetext{
* Corresponding Author:

Mohssen Nassiri-Toosi, MD Department of Liver Transplantation, Imam Khomeini Hospital, Keshavarz Blvd, Tehran, Iran

Tel: +982166581598

Fax: + 982166581521

Email: nasirito@sina.tums.ac.ir

Received: 10 Jun. 2020

Accepted: 11 Oct. 2020
}

\section{ABSTRACT}

Currently, liver transplantation (LT) is considered as the only option for the treatment of patients with various causes of liver failure, including patients with chronic hepatitis B virus (HBV) infections. Overall, patients with HBV who undergo LT are at increased risk of hepatitis B infection recurrence. Although the current knowledge regarding the pathophysiology of this infection has been dramatically increased over the past few decades, it is still considered a complex disease process with varying degrees of clinical characteristics and changing patterns over time. There are various treatment strategies for preventing HBV recurrence in the LT setting. Generally, these regimens include oral nucleoside/ nucleotide analogues (NAs), hepatitis B immune globulin (HBIG), and vaccines or the combination of these drugs. The treatment strategy of choice should be based on costeffectiveness, along with other patients underlying conditions. In this case, studies indicate that potent NAs are more cost-effective than HBIG in most case scenarios. In this article, we aimed to review the general medications used in the prophylaxis of the recurrence of HBV infection after LT.

\section{KEYWORDS:}

Liver transplantation, Hepatitis B, Treatment

Please cite this paper as:
Dooghaie Moghadam A, Eslami P, Dowlati Beirami AR, Iravani S, Farokhi E, Mansour-Ghanaei
AR, Hashemi MR, Aghajanpoor Pasha M, Mehrvar A, Nassiri-Toosi M. An Overview of the
Current Hepatitis B Treatment Strategies after Liver Transplantation. Middle East J Dig Dis
2021;13:5-14. doi: $10.34172 /$ mejdd.2021.197.
INTRODUCTION

Liver transplantation (LT) has been established as the only viable treatment option for patients with advanced liver cirrhosis. ${ }^{1,2}$ Hepatitis $B$ virus (HBV) infection is one of the most common etiologies of liver diseases worldwide, which is associated with a wide range of complications. ${ }^{3}$ It has been estimated that about 240 million people are affected by this infection globally, and more than 780,000 cases will eventually die every year because of its debilitating complications. ${ }^{4,5}$ Although the current knowledge regarding the pathophysiology of this infection has been dramatically increased over the past few decades, it is still considered a complex disease process with varying degrees of clinical characteristics and changing patterns during the time. ${ }^{6}$ Currently, the recurrence of hepatitis B following LT is still common and contributes to the major cause of death within 4-12 months after surgery. ${ }^{7}$ Recurrence of HBV after LT can be confirmed by positive HBsAg, detection of HBVDNA in serum, detection of covalently closed circular DNA (cccDNA) 
in the liver tissue, increased alanine aminotransferase, and/or present liver damage in a liver biops. ${ }^{8}$ Since the introduction of intravenous hepatitis B immunoglobulin (HBIG), a dramatic breakthrough has been noticed in preventing post-LT recurrence of hepatitis B. Moreover, additional therapeutic regimens such as antivirals nucleoside analogues (NAs) and vaccines have been used for controlling the recurrence of HBV infections. ${ }^{9}$ Despite recent advances in treatment protocols and clinical guidelines of management of hepatitis B, it is still considered as a potentially life-threatening viral infection after performing LT. ${ }^{10-13}$ In this review, the current HBV prophylactic strategies after LT is discussed.

\section{Mechanisms for reactivation of $\mathrm{HBV}$ infection after $\mathbf{L T}$}

The reasons behind HBV reactivation are still unclear, however, studies showed a unique replication strategy for HBV by forming a cccDNA in the hepatocyte nucleus, which is immune to antiviral therapies and detection by the human immune system. ${ }^{14,15}$ Another possible mechanism for the recurrence of hepatitis $B$ is the presence of HBV in extrahepatic tissues such as peripheral blood mononuclear cells (PBMCs), which can act as potential sources of reinfection. ${ }^{16}$

Risk factors for recurrent $\mathrm{HBV}$ infection after $\mathrm{LT}$ Reactivation of HBV after LT is associated with various factors such as the viral load at the time of LT, defined as HBV-DNA levels higher than 105 copies/ $\mathrm{mL}$ or $20,000 \mathrm{IU} / \mathrm{mL},{ }^{17,18} \mathrm{HBeAg}$ positivity, ${ }^{18} \mathrm{He}-$ patocellular carcinoma (HCC), ${ }^{19}$ and LT from donors with HBV infections that may significantly decrease by prophylactic therapy. ${ }^{20,21}$ Consequently, the risk of $\mathrm{HBV}$ recurrence must be evaluated before selecting the prophylactic strategy. High viral load at the time of LT, history of antiviral drug resistance, $\mathrm{HBeAg}$ positivity, HCC at LT, HCC recurrence, and having chemotherapy treatments for $\mathrm{HCC}$ are high-risk patient indicators. In contrast, low viral load, $\mathrm{HBeAg}$ negativity, acute liver failure, and hepatitis delta virus (HDV) co-infection are indicators of low-risk patients for recurrent HBV after LT. It is suggested that most high-risk patients use a combination of HBIG and NAs while low dose HBIG or even HBIG-free regimens containing potent NAs can be used in low-risk patients. ${ }^{22,23}$

Another risk factor for the recurrence of hepatitis B infection is the limitations in the administration of more effective drugs. These limitations can be due to previously existing drug resistance, drug intolerance, contraindications, or their cost. ${ }^{18,24-26}$

\section{Current drug treatment protocols}

\section{Lamivudine}

Lamivudine, a dideoxynucleoside analogue, is an antiviral drug generally used in the treatment of hepatitis B as well as human immunodeficiency virus (HIV) infections. ${ }^{27-29}$ Lamivudine is classified as nucleoside analogue reverse transcriptase inhibitors (NRTIs), and its antiviral activity is due to inhibition of reverse transcriptase enzyme in the form of lamivudine triphosphate. ${ }^{27,29,30}$ Phosphorylation of lamivudine is critical for antiviral activity. In contrast, the reverse transcriptase enzymes of HIV and polymerase of HBV exhibit pyrophosphorolysis activity, which results in resistance to lamivudine and dideoxynucleoside analogs. ${ }^{30,31}$ The recommended dose for lamivudine in patients with normal creatinine clearance is $100 \mathrm{mg}$ orally once-daily ${ }^{32}$ and has been shown to be safe in adults, ${ }^{33}$ children, ${ }^{34}$ and even during pregnancy. ${ }^{35}$ Also, studies strongly recommend the use of lamivudine in the prevention of HBV of mother-to-child transmission, which is one of the most common transmission modes of HBV. ${ }^{36}$ On the other hand, several meta-analyses showed a less favorable outcome of using lamivudine in the treatment and prevention of reactivation compared with entecavir or tenofovir .${ }^{37-39} \mathrm{It}$ is worth mentioning that sorbitol, as a common liquid excipient, has an impact on decreasing the absorption of lamivudine. ${ }^{40}$ Therefore, co-administration of sorbitol-containing medicines should be generally avoided.

\section{Adefovir dipivoxil}

Adefovir is another oral nucleoside/nucleotide analogue (NA) with a similar mechanism to lamivudine. ${ }^{41} \mathrm{It}$ is also approved in the treatment of chronic hepatitis 
B (CHB) with an oral dose of $10 \mathrm{mg}$ once daily. ${ }^{41,42}$ One of the advantages of adefovir over lamivudine is the less chance of developing resistance. Also, studies showed that a combination of lamivudine plus adefovir is effective in lamivudine-resistant patients with CHB. ${ }^{42-44}$

\section{Entecavir}

Similar to adefovir and lamivudine, entecavir is an oral NA, and it is approved for CHB infection .$^{41,42}$ In patients with no renal dysfunction, entecavir is suggested $0.5 \mathrm{mg}$ daily for adults, and $1 \mathrm{mg}$ in lamivudine experienced patients and patients with decompensated cirrhosis. ${ }^{45}$ Entecavir is also preferred to lamivudine and adefovir in recent Hepatitis B Guidance. ${ }^{45}$

\section{Tenofovir dipovoxil fumarate}

Tenofovir dipovoxil fumarate is the prodrug of tenofovir, which is also used in the treatment of chronic HBV. It is an NA in the mediational class of NRTIs. ${ }^{46,47}$ Tenofovir exhibits a longer half-life in both serum and intracellular media compared with other NAs. ${ }^{48}$ Tenofovir dipovoxil fumarate is recommended as $300 \mathrm{mg}$ daily for adults and children aged $\geq 12$ years with normal renal function..$^{45}$

\section{Immunization therapies}

HBIG is a human immune globulin against hepatitis B surface antigen (HBsAg). ${ }^{49} \mathrm{HBIG}$ is known to be used for the prevention of HBV reactivation and in situations of acute exposure to HBV. ${ }^{49}, 50$ Studies showed that a combination of HBIG and NAs is significantly effective in the prevention of HBV reactivation. ${ }^{51-53}$ In contrast with HBIG, the vaccine causes active immunity by exposure of a subunit (an antigen) to the immune system. ${ }^{54} \mathrm{~A}$ study by Bienzle and colleagues showed the possibility of successful vaccination after $\mathrm{LT}^{55}$

\section{Management strategies of $\mathrm{HBV}$ in patients on the waiting list}

There are several studies on the prevention of HBV reactivation after LT. Antiviral drugs may differ in safety, efficacy, rate of resistance, and long-term clinical outcome, alone and/or in combination with other antiviral drugs. ${ }^{52,56,57} \mathrm{~A}$ summary of the studies is represented in Table 1. Extending waiting time for patients in the waiting-list of LT due to CHB by effective suppression of infection can be lifesaving.$^{58}$ In a study by Gane and co-workers, administration of lamivudine plus adefovir, which is initiated at the time of being on the waiting list, was safe and effective against reactivation of $\mathrm{HBV}^{59}$

\section{Management strategies of prevention of $\mathrm{HBV}$} reactivation in patients after $\mathbf{L T}$

\section{HBIG monotherapy}

Induction of passive immunity by administering HBIG with or without antivirals has been the gold standard for the prevention of HBV reactivation, and many studies support the effectiveness of using HBIG. ${ }^{60-62}$ However, controversies on the dose, duration, and route of (administration Intravenous(IV), Intramuscular (IM), or Subcutaneous (SC)) still exist. ${ }^{63}$ In a study done by Avolio and colleagues, ${ }^{64}$ 16 patients with the mean Model For End-Stage Liver Disease score) MELD Score (of $19 \pm 9$, were assessed for HBV reactivation. Ten patients were found to be at risk for recurrence, and 10,000 IU of HBIG were administered at the end of the anhepatic phase, followed by 5,000 IU for the next 7 days. Subsequently, the doses of HBIG were adjusted to maintain anti-HBs $>400 \mathrm{U} / \mathrm{L}$ in the first three months and $>200 \mathrm{U} / \mathrm{L}$ afterward. The recurrence rate was $30 \%$ in this group. In contrast, in a study by Terrault and others, ${ }^{61}$ 10,000 IU of HBIG were administered daily during the anhepatic phase for the next 7 days and continued monthly afterward. The recurrence rate was $19 \%$ in patients who received HBIG, while it was $76 \%$ in patients who did not receive the prophylaxis regimen. The adverse effects of HBIG are rare, but there is the possibility of anaphylaxis/hypersensitivity reactions and thrombotic events, which should be considered. ${ }^{65,66}$

\section{NA monotherapy}

Monotherapies of NA in the prophylaxis of HBV recurrence were studied due to the high cost and 


\section{8 \\ Hepatitis B Treatments after Liver Transplantation}

Table 1: Clinical studies on the management of patients with HBV after liver transplantation

\begin{tabular}{|c|c|c|c|c|c|}
\hline Patients' information & study approach & $\begin{array}{l}\text { Time of } \\
\text { study }\end{array}$ & result & Description & Ref. \\
\hline $\begin{array}{l}17 \text { HBsAg positive } \\
\text { patients }\end{array}$ & $\begin{array}{l}13 \text { patients received a high dose } \\
\text { of } \mathrm{HBIG}(\mathrm{A}), 4 \text { patients did not } \\
\text { receive HBIG (B) }\end{array}$ & & $\begin{array}{l}\text { A: } 10 \text { of } 13 \text { patients did not } \\
\text { experience recurrence. } \\
\text { B: all patients reoccurred } \\
\text { within } 3 \text { months. }\end{array}$ & & 62 \\
\hline $\begin{array}{l}52 \mathrm{HBs} A g \text {-positive } \\
\text { patients }\end{array}$ & $\begin{array}{l}24 \text { patients received a high dose } \\
\text { of } \mathrm{HBIG}(\mathrm{A}), 28 \text { patients did not } \\
\text { receive therapy (B) }\end{array}$ & 2 years & $\begin{array}{l}\text { A: } 19 \% \text { of patients did not } \\
\text { experience recurrence. } \\
\text { B: } 76 \% \text { of patients reoccurred } \\
\text { within } 3 \text { months }\end{array}$ & & 61 \\
\hline 52 patients with $\mathrm{CHB}$ & $\begin{array}{l}\text { All patients received } 100 \mathrm{mg} \text { of } \\
\text { lamivudine daily }\end{array}$ & 52 weeks & $\begin{array}{c}60 \% \text { of patients had unde- } \\
\text { tectable HBV DNA after } \\
\text { treatment }\end{array}$ & $\begin{array}{l}\text { Also, serum alanine } \\
\text { transaminase levels } \\
\text { normalized in } 71 \%\end{array}$ & 67 \\
\hline $\begin{array}{l}24 \text { HBsAg-positive } \\
\text { patients who had received } \\
\text { HBIG for at least } 6 \\
\text { months }\end{array}$ & $\begin{array}{l}\text { A: treated with lamivudine }(\mathrm{n}=12), \mathrm{B} \text { : } \\
\text { treated with } \operatorname{HBIG}(\mathrm{n}=12)\end{array}$ & 52 weeks & $\begin{array}{c}\text { A: } 10 \text { of } 12 \text { without } \\
\text { recurrence } \\
\text { B: } 11 \text { of } 12 \text { without recur- } \\
\text { rence }\end{array}$ & $\begin{array}{l}\text { This study recommends } \\
\text { a cost-effectiveness } \\
\text { study due to the similar } \\
\text { efficacy of both HBIG } \\
\text { and lamivudine. }\end{array}$ & 94 \\
\hline $\begin{array}{l}47 \mathrm{HBsAg} \text { positive LT } \\
\text { candidates }\end{array}$ & $\begin{array}{l}\text { All patients treated with } 100 \mathrm{mg} \\
\text { lamivudine daily without } \mathrm{HBIG}\end{array}$ & 38 months & $\begin{array}{c}60 \% \text { of patients were } \\
\text { HBsAg negative } 12 \text { weeks } \\
\text { after LT }\end{array}$ & & 68 \\
\hline $\begin{array}{l}80 \text { patients who had } \\
\text { post-transplant prophy- } \\
\text { laxis of lamivudine and } \\
\text { HBIG }\end{array}$ & $\begin{array}{l}\text { Lamivudine (300 mg/day) plus } \\
\text { HBIG (200-400 IU/2-4 weeks) }\end{array}$ & 21 months & $\begin{array}{l}\text { Recurrence occurred in } 4 \% \\
\text { of patients. }\end{array}$ & & 52 \\
\hline $\begin{array}{l}42 \text { post-LT patients with } \\
\text { lamivudine-resistant } \\
\text { HBV infection }\end{array}$ & Adefovir (10 mg/day) & $\begin{array}{l}12 \text { to } 31 \\
\text { months }\end{array}$ & $\begin{array}{c}\text { In } 64 \% \text { of patients, serum } \\
\text { HBV-DNA was undetect- } \\
\text { able }\end{array}$ & $\begin{array}{l}\text { ALT levels decreased } \\
\text { significantly in } 62.9 \% \\
\text { of cases. }\end{array}$ & 69 \\
\hline $\begin{array}{l}30 \text { HBsAg positive } \\
\text { patients }\end{array}$ & $5 \%$ HBIG plus lamivudine & 36 months & $\begin{array}{l}\text { Recurrence occurred in } \\
\text { only one patient. }\end{array}$ & $\begin{array}{l}\text { The study showed the } \\
\text { safety and efficacy } \\
\text { of high dose HBIG } \\
\text { in combination with } \\
\text { lamivudine. }\end{array}$ & 76 \\
\hline $\begin{array}{l}14 \mathrm{HBsAg} \text { positive } \\
\text { patients }\end{array}$ & $\begin{array}{l}\text { Lamivudine plus adefovir }(\mathrm{n}=13) \text { and } \\
\text { lamivudine plus tenofovir }(\mathrm{n}=1)\end{array}$ & 32 months & $\begin{array}{l}\text { Only one patient who } \\
\text { had very high HBV-DNA } \\
\text { remained HBsAg positive. }\end{array}$ & $\begin{array}{l}\text { This study suggested not } \\
\text { using HBIG in mainte- } \\
\text { nance therapy, which is } \\
\text { cost-effective. }\end{array}$ & 77 \\
\hline $\begin{array}{l}20 \text { HBsAg positive } \\
\text { patients }\end{array}$ & $\begin{array}{l}\text { Lamivudine ( } 100 \mathrm{mg} \text { daily) plus } \\
\text { adefovir ( } 10 \mathrm{mg} \text { daily) }\end{array}$ & 36 months & $\begin{array}{l}\text { none of the patients had a } \\
\text { recurrence of hepatitis } B \text {. }\end{array}$ & & 59 \\
\hline Eight patients & $\begin{array}{l}\text { Entecavir and/or tenofovir after LT } \\
\text { for treatment or prevention of HBV } \\
\text { infection }\end{array}$ & 12 months & $\begin{array}{l}\text { No significant side effects } \\
\text { were observed during the } \\
\text { follow-up period. }\end{array}$ & & 56 \\
\hline 14 patients & $\begin{array}{l}\text { A: Eight patients received lamivu- } \\
\text { dine before LT which one of them } \\
\text { converted to entecavir after LT, B: } \\
\text { Two patients received lamivudine } \\
\text { plus adefovir, C: four patients did } \\
\text { not receive NAs which one of them } \\
\text { received entecavir, one of them } \\
\text { received lamivudine plus adefovir, } \\
\text { and two of them received lamivu- } \\
\text { dine after LT. } \\
\text { All patients received } 20,000 \mathrm{U} \text { of } \\
\text { HBIG at day } 0 \text { after LT, } 10,000 \mathrm{U} \text { at } \\
\text { day } 1 \text { after LT, } 10,000 \text { at day } 2 \text { after } \\
\text { LT, a monthly maintenance dose } \\
(2,000-3,000 \mathrm{U}) \text { to keep IG level at } \\
100-150 \mathrm{U} / \mathrm{L} \text { for one year. }\end{array}$ & 42 months & $\begin{array}{l}\text { Only two patients had a } \\
\text { recurrence of hepatitis B. }\end{array}$ & & 95 \\
\hline 23 patients & $\begin{array}{l}\text { Patients switched from monthly IV } \\
\text { to weekly SC use of a novel HBIG: } \\
\text { BT088 (Zutectra) }\end{array}$ & 18 weeks & $\begin{array}{l}\text { None of the patients had a } \\
\text { recurrence of hepatitis B. }\end{array}$ & $\begin{array}{l}\text { BT088 is effective, safe, } \\
\text { and presents an } \\
\text { easy-to-apply treatment } \\
\text { option. }\end{array}$ & 96 \\
\hline $\begin{array}{l}17 \text { patients with hepati- } \\
\text { tis-related diseases }\end{array}$ & $\begin{array}{l}\text { Patients received both lamivudine } \\
\text { and HBIG for less than } 18 \text { months } \\
\text { and discontinued HBIG. }\end{array}$ & $\begin{array}{l}42-86 \\
\text { months }\end{array}$ & $\begin{array}{l}\text { Two patients had HBV } \\
\text { recurrence. }\end{array}$ & $\begin{array}{l}\text { Two patients were ex- } \\
\text { cluded from the study }\end{array}$ & 79 \\
\hline
\end{tabular}




\begin{tabular}{|c|c|c|c|c|c|}
\hline Patients' information & study approach & $\begin{array}{l}\text { Time of } \\
\text { study }\end{array}$ & result & Description & Ref. \\
\hline 29 patients & $\begin{array}{l}\text { Patients received } 0.5 \mathrm{mg} \text { of enteca- } \\
\text { vir for more than } 2 \text { years and HBIG } \\
\text { only in the first year after LT. }\end{array}$ & 31 months & $\begin{array}{l}\text { None of the patients had a } \\
\text { recurrence of hepatitis } B \text {. }\end{array}$ & $\begin{array}{c}\text { one of the patients had } \\
\text { HCC recurrence }\end{array}$ & 78 \\
\hline $\begin{array}{l}24 \text { adults with } \mathrm{HBV}- \\
\text { related } \\
\text { liver disease }\end{array}$ & $\begin{array}{l}\text { Tenofovir disoproxil fumarate (with } \\
\text { or without lamivudine) and HBIG } \\
\text { (only in the first year after LT) were } \\
\text { used to prevent recurrence of HBV } \\
\text { infection. }\end{array}$ & $\begin{array}{l}29.1 \\
\text { months }\end{array}$ & $\begin{array}{l}\text { None of the patients had a } \\
\text { recurrence of hepatitis B. }\end{array}$ & $\begin{array}{l}\text { Patient survival in } 1 \\
\text { year: } 100 \% \\
\text { Patient survival in } 5 \\
\text { years: } 84.1 \%\end{array}$ & 80 \\
\hline $\begin{array}{l}71 \mathrm{HBs} A g \text { negative } \\
\text { patients who received } \\
\text { anti-HBc positive grafts }\end{array}$ & $\begin{array}{l}\text { Patients received HBV vaccinations. } \\
24 \text { patients with high anti-HBs } \\
\text { titer before LT did not receive } \\
\text { prophylaxis(A). } \\
30 \text { patients responded to vaccination } \\
\text { and received lamivudine (B). } \\
17 \text { patients did not respond to vacci- } \\
\text { nation and received lamivudine (C). }\end{array}$ & 24 months & $\begin{array}{l}\text { Only patients of group C } \\
\text { developed De novo hepati- } \\
\text { tis B infection. }\end{array}$ & & 89 \\
\hline
\end{tabular}

incompliances of HBIG administration and described in Table $1 .^{67-71}$ Lamivudine with a daily dose of 100 $\mathrm{mg}$ is the most studied prophylaxis for HBV reactivation. ${ }^{67,68}$ However, due to its renal elimination, doses may be adjusted related to creatinine clearance (CrCl). ${ }^{72}$ However, until $\mathrm{CrCl}$ is $<30 \mathrm{~mL} / \mathrm{min}$, dosage adjustment can be avoided. Also, a study showed no side effect in using $300 \mathrm{mg}$ daily for patients with $\mathrm{CrCl}$ higher than $30 \mathrm{~mL} / \mathrm{min}, 150 \mathrm{mg}$ daily for patients with $\mathrm{CrCl}$ between 15 and $29 \mathrm{~mL} / \mathrm{min}$, and 100-150 $\mathrm{mg}$ daily for patients with $\mathrm{CrCl}$ less than $15 \mathrm{~mL} / \mathrm{min}$ or patients on hemodialysis. In this study, the maximum serum concentration of these three groups were approximately $3.30,3.48$, and 3.21 , respectively. ${ }^{24}$ On the other hand, adefovir monotherapy showed similar efficacy to lamivudine, ${ }^{69}$ and it needs dose adjustment in renal dysfunctions. Dosage intervals should be adjusted in patients with $\mathrm{CrCl}$ less than 50 $\mathrm{mL} / \mathrm{min}^{73}$ For tenofovir disoproxil fumarate, dose adjustments must be applied for patients with $\mathrm{CrCL}$ $<50 \mathrm{ml} / \mathrm{min}$. Patients with $\mathrm{CrCl}$ between 30 and 49 $\mathrm{mL} / \mathrm{min}$ should receive double the interval administered by patients with $\mathrm{CrCl} \geq 50 \mathrm{~mL} / \mathrm{min}$. Patients with CrCL between 10 and $29 \mathrm{~mL} / \mathrm{min}$ should use tenofovir disoproxil fumarate once or twice weekly. For hemodialysis patients, tenofovir disoproxil can be used after each hemodialysis or every 7 days. ${ }^{74}$ Tenofovir is also safe and tolerable for both mother and infant in pregnancy, according to a meta-analysis done by Wenhui and colleagues. ${ }^{75}$

\section{Combination therapy}

The most successful prophylaxis of HBV reinfection can be achieved by combination therapies. ${ }^{52,59,76-78}$ Monotherapy with HBIG or NAs results in similar effectiveness ${ }^{78}$, while co-administration of both HBIG and NAs shows a better outcome in the prophylaxis of HBV reinfection..$^{52,59,76-78}$ Most studies that used a combination of HBIG and NAs for prophylaxis used HBIG only after LT or for a short period after LT. ${ }^{78-80}$ Nassiri-Toosi and co-workers demonstrated that lowdose intramuscular HBIG injection with oral agents of tenofovir or lamivudine and discontinuation of HBIG after one year post-liver transplantation can provide safe protection and plays a preventive role against hepatitis $\mathrm{B}$ reinfection after transplantation. Additionally, another study done by Nassiri-Toosi and colleagues showed that this combination was also cost-effective in preventing the recurrence of hepatitis B. ${ }^{81-83}$ On the other hand, a combination of $100 \mathrm{mg}$ lamivudine daily and $10 \mathrm{mg}$ adefovir daily showed no recurrence of hepatitis $\mathrm{B}$ in a follow up of 36 months. ${ }^{59}$

\section{Vaccination}

Inducing active immunity for the prevention of HBV reactivation can be another prophylaxis strategy, but despite the potential efficacy of vaccines, studies have failed to confirm an acceptable outcome of using vaccines. ${ }^{71}$ This might be due to the immune system's inability to develop an effective response to the continuous exposure of patients with chronic hepatitis B to HBV antigens before LT. ${ }^{84,85}$ A study on 
52 patients who were on lamivudine prophylaxis and received two courses of double-dose recombinant HBV vaccine showed a limited efficacy for the recombinant $\mathrm{HBV}$ vaccine.$^{85}$ Nevertheless, vaccines targeting the preS1 domain, which can potentially overcome immune tolerance in $\mathrm{HBV}$, are showing promising efficacy in developing immune response in clinical studies. ${ }^{86-88}$ On the other hand, HBV vaccines might be more effective in the prophylaxis of de novo hepatitis $B$ infection in HBsAg negative patients who receive grafts from anti-HBc positive donors. In a study on $71 \mathrm{HBs} A g$ negative patients who received anti-HBc positive grafts, 54 who received HBV vaccine did not develop de novo hepatitis B infection. ${ }^{89}$

\section{Discontinuation of all prophylaxis}

A study by Lenci and colleagues shows a low rate of $\mathrm{HBV}$ recurrence in patients with no detectable HBV cccDNA and a total HBV in intrahepatic and blood in 2 years after the discontinuation of prophylaxis. ${ }^{90}$ However, it is not suggested due to the lack of sufficient and long-term studies. ${ }^{90,91}$ A systematic review by Cholongitas E. et al. suggested prophylaxis with lamivudine HBsAg-negative patients and no prophylaxis for both anti-HBc and anti-HBs positive patients. $^{92}$

\section{Monitoring for $\mathrm{HBV}$ recurrence}

The best monitoring protocol cannot be determined due to the lack of comparative studies. ${ }^{93}$ However, it is suggested to monitor HBsAg and HBV DNA every 3 months in the first year after LT and in HBsAg positive recipients or patients who receive a graft from an $\mathrm{HBcAb}$ positive donor, it should be continued every 6 months after the first year regardless of prophylaxis or treatment regimen. ${ }^{93}$ Also, in self-reported or suspected non-adherence cases monitoring intervals should be shortened..$^{93}$

\section{CONCLUSION}

Although most studies show satisfying outcomes in the prevention of hepatitis B recurrence using HBIG with or without NAs, there is no clear strategy of prophylaxis yet. Two parameters should be considered in making the decision to choose the medication regimen: first, the effectiveness of the regimen in the prevention of HBV reinfection and second, its cost. Thus, the cost-effectiveness studies are crucial for each health care systems. Also, several recent studies showed similar efficacy in both combination therapies involving with or without HBIG usage, which suggests the fact that HBIG can be replaced with low-cost potent NAs. Furthermore, other factors, including drug interactions, HBV co-infection (such as HDV and HIV), renal dysfunctions, and resistance or intolerances to regimen must be considered in prescribing prophylaxis before and/or after LT. On the other hand, NAs and HBIG provide the state of control by suppressing the viral reactivation and does not affect stealth HBV (e.g., cccDNA in hepatocytes and extrahepatic HBV). Induction of active immunity via vaccinations and administration of cccDNA inhibitors might be a future solution for the prevention of HBV reactivation after LT.

\section{ETHICAL APPROVAL}

There is nothing to be declared.

\section{CONFLICT OF INTEREST}

The authors declare no conflict of interest related to this work.

\section{REFERENCES}

1. Jafarian A, Toosi MN, Salimi J, Najafi A, Moeeni M, Ahmadinejad Z, et al. Experience Of The First 20 Liver Transplantations Failures And Successes: 2007. Transplantation 2008;86:659. doi: 10.1097/01.tp.0000330699.17163.46.

2. Razavi-Khorasani N, Moazzami B, Dooghaie Moghadam A, Eslami P, Farokhi E, Mehrvar A, et al. Pulmonary Complications in Candidates for Liver Transplantation. Middle East $J$ Dig Dis 2020;12:145-53. doi: 10.34172/mejdd.2020.176.

3. Roushan N, Bashiri K, Meysamie A, Nasiri Toosi M. Health Literacy Disparities about Hepatitis B: A National Assessment in Iran. Iran J Virology 2014;8:18-25.

4. Beckebaum S, Herzer K, Bauhofer A, Gelson W, De Simone P, de Man R, et al. Recurrence of Hepatitis B Infection in Liver Transplant Patients Receiving Long-Term Hepatitis B Immunoglobulin Prophylaxis. Ann Transplant 2018;23:789801. doi: 10.12659/AOT.910176.

5. Lozano R, Naghavi M, Foreman K, Lim S, Shibuya K, Aboyans V, et al. Global and regional mortality from 235 causes of death for 20 age groups in 1990 and 2010: a systematic analysis for the Global Burden of Disease Study 2010. Lancet 2012;380:2095-128. doi: 10.1016/S0140-6736(12)61728-0.

6. Nelson NP, Easterbrook PJ, McMahon BJ. Epidemiology 
of Hepatitis B Virus Infection and Impact of Vaccination on Disease. Clin Liver Dis 2016;20:607-28. doi: 10.1016/j. cld.2016.06.006.

7. Schoening WN, Buescher N, Rademacher S, Andreou A, Kuehn S, Neuhaus R, et al. Twenty-year longitudinal follow-up after orthotopic liver transplantation: a single-center experience of 313 consecutive cases. Am J Transplant 2013;13:2384-94. doi: 10.1111/ajt.12384.

8. Jiménez-Pérez M, González-Grande R, Mostazo Torres J, González Arjona C, Rando-Muñoz FJ. Management of hepatitis B virus infection after liver transplantation. World $J$ Gastroenterol 2015;21:12083-90. doi: 10.3748/wjg.v21. i42.12083.

9. Sarin SK, Kumar M, Lau GK, Abbas Z, Chan HLY, Chen $\mathrm{CJ}$, et al. Asian-Pacific clinical practice guidelines on the management of hepatitis B: a 2015 update. Hepatol Int 2016;10:1-98. doi: 10.1007/s12072-015-9675-4.

10. Ikeda K, Shiga Y, Takahashi A, Kai T, Kimura H, Takeyama $\mathrm{K}$, et al. Fatal hepatitis $\mathrm{B}$ virus reactivation in a chronic myeloid leukemia patient during imatinib mesylate treatment. Leuk Lymphoma 2006;47:155-7. doi: 10.1080/14639230500236818.

11. Wu JM, Huang YH, Lee PC, Lin HC, Lee SD. Fatal reactivation of hepatitis B virus in a patient who was hepatitis B surface antigen negative and core antibody positive before receiving chemotherapy for non-Hodgkin lymphoma. J Clin Gastroenterol 2009;43:496-8. doi: 10.1097/MCG.0b013e3181945942.

12. Gwak GY, Koh KC, Kim HY. Fatal hepatic failure associated with hepatitis B virus reactivation in a hepatitis B surface antigen-negative patient with rheumatoid arthritis receiving low dose methotrexate. Clin Exp Rheumatol 2007;25:888-9.

13. Lau JY, Lai CL, Lin HJ, Lok AS, Liang RH, Wu PC, et al. Fatal reactivation of chronic hepatitis $\mathrm{B}$ virus infection following withdrawal of chemotherapy in lymphoma patients. QJ Med 1989;73:911-7.

14. Allweiss L, Dandri M. The Role of cccDNA in HBV Maintenance. Viruses 2017;9:156. doi: 10.3390/v9060156.

15. Wong DK, Seto WK, Fung J, Ip P, Huang FY, Lai CL, et al. Reduction of hepatitis B surface antigen and covalently closed circular DNA by nucleos $(\mathrm{t})$ ide analogues of different potency. Clin Gastroenterol Hepatol 2013;11:1004-10.e1. doi: 10.1016/j. cgh.2013.01.026.

16. Coffin CS, Mulrooney-Cousins PM, van Marle G, Roberts JP, Michalak TI, Terrault NA. Hepatitis B virus quasispecies in hepatic and extrahepatic viral reservoirs in liver transplant recipients on prophylactic therapy. Liver Transpl 2011;17:955-62. doi: 10.1002/1t.22312.

17. Marzano A, Gaia S, Ghisetti V, Carenzi S, Premoli A, Debernardi-Venon W, et al. Viral load at the time of liver transplantation and risk of hepatitis B virus recurrence. Liver Transpl 2005;11:402-9. doi: 10.1002/lt.20402.

18. Roche B, Samuel D. Withdrawal of posttransplant hepatitis B virus prophylaxis: A blind test. Liver Transpl 2016;22:1183-5. doi: 10.1002/lt.24511.

19. Faria LC, Gigou M, Roque-Afonso AM, Sebagh M, Roche B, Fallot G, et al. Hepatocellular carcinoma is associated with an increased risk of hepatitis B virus recurrence after liver transplantation. Gastroenterology 2008;134:1890-9; quiz 2155. doi: 10.1053/j.gastro.2008.02.064.

20. Mandalà M FS, Francisci D, Bruno R, Merelli B, Pasulo L et al. Hepatitis B in immunosuppressed cancer patients: Pathogenesis, incidence and prophylaxis. Crit Rev Oncol Hematol 2013;87:12-27. doi: 10.1016/j.critrevonc.2012.12.004.

21. Ayoub WS, Martin P, Bhamidimarri KR. Hepatitis B Virus Infection and Organ Transplantation. Gastroenterol Hepatol 2018;14:33-40.

22. Maiwall R, Kumar M. Prevention and Treatment of Recurrent Hepatitis B after Liver Transplantation. J Clin Transl Hepatol 2016;4:54-65. doi: 10.14218/JCTH.2015.00041.

23. Chauhan R, Lingala S, Gadiparthi C, Lahiri N, Mohanty SR, $\mathrm{Wu} \mathrm{J}$, et al. Reactivation of hepatitis B after liver transplantation: Current knowledge, molecular mechanisms and implications in management. World J Hepatol 2018;10:35270. doi: 10.4254/wjh.v10.i3.352.

24. Fischetti B, Shah K, Taft DR, Berkowitz L, Bakshi A, Cha A. Real-World Experience With Higher-Than-Recommended Doses of Lamivudine in Patients With Varying Degrees of Renal Impairment. Open Forum Infect Dis 2018;5:ofy225-ofy. doi: 10.1093/ofid/ofy225. eCollection 2018 Oct.

25. Fox AN, Terrault NA. The option of HBIG-free prophylaxis against recurrent HBV. J Hepatol 2012;56:1189-97. doi: 10.1016/j.jhep.2011.08.026.

26. Chung EH. Vaccine allergies. Clin Exp Vaccine Res 2014;3:507. doi: 10.7774/cevr.2014.3.1.50.

27. Perry CM, Faulds D. Lamivudine. A review of its antiviral activity, pharmacokinetic properties and therapeutic efficacy in the management of HIV infection. Drugs 1997;53:657-80. doi: 10.2165/00003495-199753040-00008.

28. Hagmeyer KO, Pan YY. Role of lamivudine in the treatment of chronic hepatitis B virus infection. Ann Pharmacother 1999;33:1104-12. doi: 10.1345/aph.18452.

29. Dando TM, Scott LJ. Abacavir plus lamivudine: a review of their combined use in the management of HIV infection. Drugs 2005;65:285-302. doi: 10.2165/00003495-20056502000010.

30. Kamiya N. The mechanisms of action of antivirals against hepatitis B virus infection. $J$ Antimicrob Chemother 2003;51:1085-9. doi: 10.1093/jac/dkg236.

31. Das K, Xiong X, Yang H, Westland CE, Gibbs CS, Sarafianos $\mathrm{SG}$, et al. Molecular modeling and biochemical characterization reveal the mechanism of hepatitis B virus polymerase resistance to lamivudine (3TC) and emtricitabine (FTC). J Virol 2001;75:4771-9. doi: 10.1128/JVI.75.10.4771-4779.2001.

32. Bhattacharya D, Thio CL. Review of hepatitis B therapeutics. Clin Infect Dis 2010;51:1201-8. doi: 10.1086/656624.

33. Lok AS, Lai CL, Leung N, Yao GB, Cui ZY, Schiff ER, et 
al. Long-term safety of lamivudine treatment in patients with chronic hepatitis B. Gastroenterology 2003;125:1714-22. doi: 10.1053/j.gastro.2003.09.033.

34. Luo A, Jiang X, Ren H. Lamivudine therapy for chronic hepatitis B in children: a meta-analysis. Virol J 2019;16:88. doi: 10.1186/s12985-019-1193-x.

35. Brown RS, Jr., McMahon BJ, Lok AS, Wong JB, Ahmed AT, Mouchli MA, et al. Antiviral therapy in chronic hepatitis B viral infection during pregnancy: A systematic review and meta-analysis. Hepatology 2016;63:319-33. doi: 10.1002/ hep. 28302 .

36. Khalighinejad P, Alavian SM, Fesharaki MG, Jalilianhasanpour R. Lamivudine's efficacy and safety in preventing mother-to-child transmission of hepatitis B: A meta-analysis. Turk J Gastroenterol 2019;30:66-74. doi: 10.5152/tjg.2018.18148.

37. Huang K-W, Tam K-W, Luo J-C, Kuan Y-C. Efficacy and Safety of Lamivudine Versus Entecavir for Treating Chronic Hepatitis B Virus-related Acute Exacerbation and Acuteon-Chronic Liver Failure: A Systematic Review and MetaAnalysis. J Clin Gastroenterol 2017;51:539-47. doi: 10.1097/ MCG.0000000000000675.

38. Govan L, Wu O, Xin Y, Hutchinson SJ, Hawkins N. Comparative effectiveness of antiviral treatment for hepatitis B: a systematic review and Bayesian network meta-analysis. Eur J Gastroenterol Hepatol 2015;27:882-94. doi: 10.1097/ MEG.0000000000000376.

39. Yang C, Qin B, Yuan Z, Chen L, Zhou HY. Meta-analysis of prophylactic entecavir or lamivudine against hepatitis $\mathrm{B}$ virus reactivation. Ann Hepatol 2016;15:501-11.

40. Adkison K, Wolstenholme A, Lou Y, Zhang Z, Eld A, Perger T, et al. Effect of Sorbitol on the Pharmacokinetic Profile of Lamivudine Oral Solution in Adults: An Open-Label, Randomized Study. Clin Pharmacol Ther 2018;103:402-8. doi: 10.1002/cpt.943.

41. Fung J, Lai CL, Seto WK, Yuen MF. Nucleoside/nucleotide analogues in the treatment of chronic hepatitis B. J Antimicrob Chemother 2011;66:2715-25. doi: 10.1093/jac/dkr388.

42. De Clercq E, Férir G, Kaptein S, Neyts J. Antiviral treatment of chronic hepatitis B virus (HBV) infections. Viruses 2010;2:1279-305. doi: 10.3390/v2061279.

43. Sheng Y-J, Liu J-Y, Tong S-W, Hu H-D, Zhang D-Z, Hu P, et al. Lamivudine plus adefovir combination therapy versus entecavir monotherapy for lamivudine-resistant chronic hepatitis B: a systematic review and meta-analysis. Virol $J$ 2011;8:393. doi: 10.1186/1743-422X-8-393.

44. Yatsuji H, Suzuki F, Sezaki H, Akuta N, Suzuki Y, Kawamura $\mathrm{Y}$, et al. Low risk of adefovir resistance in lamivudine-resistant chronic hepatitis B patients treated with adefovir plus lamivudine combination therapy: two-year follow-up. J Hepatol 2008;48:923-31. doi: 10.1016/j.jhep.2008.02.019.

45. Terrault NA, Lok ASF, McMahon BJ, Chang KM, Hwang JP, Jonas MM, et al. Update on prevention, diagnosis, and treatment of chronic hepatitis B: AASLD 2018 hepatitis
B guidance. Hepatology 2018;67:1560-99. doi: 10.1002/ hep. 29800 .

46. Bongiovanni M, Tordato F. Tenofovir plus didanosine as Nrti backbone in HIV-infected subjects. Curr Med Chem 2006;13:2789-93. doi: 10.2174/092986706778521931.

47. Lyseng-Williamson KA, Reynolds NA, Plosker GL. Tenofovir disoproxil fumarate: a review of its use in the management of HIV infection. Drugs 2005;65:413-32. doi: 10.2165/00003495-200565030-00006.

48. Kearney BP, Flaherty JF, Shah J. Tenofovir disoproxil fumarate: clinical pharmacology and pharmacokinetics. Clin Pharmacokinet 2004;43:595-612. doi: 10.2165/00003088200443090-00003.

49. Habib S, Shaikh OS. Hepatitis B immune globulin. Drugs Today (Barc) 2007;43:379-94. doi: 10.1358/ dot.2007.43.6.1050792.

50. Hoofnagle JH, Seeff LB, Bales ZB, Wright EC, Zimmerman HJ. Passive-active immunity from hepatitis B immune globulin. Reanalysis of a Veterans Administration cooperative study of needle-stick hepatitis. The Veterans Administration Cooperative Study Group. Ann Intern Med 1979;91:813-8. doi: 10.7326/0003-4819-91-6-813.

51. Angus PW, McCaughan GW, Gane EJ, Crawford DH, Harley H. Combination low-dose hepatitis B immune globulin and lamivudine therapy provides effective prophylaxis against posttransplantation hepatitis B. Liver Transpl 2000;6:429-33. doi: 10.1053/jlts.2000.8310.

52. Karasu Z, Ozacar T, Akyildiz M, Demirbas T, Arikan C, Kobat A, et al. Low-dose hepatitis B immune globulin and higher-dose lamivudine combination to prevent hepatitis $\mathrm{B}$ virus recurrence after liver transplantation. Antivir Ther 2004;9:921-7.

53. Takaki A, Yagi T, Yamamoto K. Safe and cost-effective control of post-transplantation recurrence of hepatitis B. Hepatol Res 2015;45:38-47. doi: 10.1111/hepr.12368.

54. Baxter D. Active and passive immunity, vaccine types, excipients and licensing. Occup Med 2007;57:552-6. doi: 10.1093/occmed/kqm110.

55. Bienzle U, Günther M, Neuhaus R, Vandepapeliere P, Vollmar $\mathrm{J}$, Lun A, et al. Immunization with an adjuvant hepatitis B vaccine after liver transplantation for hepatitis B-related disease. Hepatology 2003;38:811-9. doi: 10.1053/jhep.2003.50396.

56. Jiménez-Pérez M, Sáez-Gómez AB, Mongil Poce L, LozanoRey JM, de la Cruz-Lombardo J, Rodrigo-López JM. Efficacy and safety of entecavir and/or tenofovir for prophylaxis and treatment of hepatitis B recurrence post-liver transplant. Transplant Proc 2010;42:3167-8. doi: 10.1016/j.transproceed.2010.05.127.

57. Buti M, Tabernero D, Mas A, Homs M, Prieto M, RodríguezFrías $\mathrm{F}$, et al. Hepatitis B virus quasispecies evolution after liver transplantation in patients under long-term lamivudine prophylaxis with or without hepatitis B immune globulin. Transpl Infect Dis 2015;17:208-20. doi: 10.1111/tid.12360. 
58. Schiff E, Lai CL, Hadziyannis S, Neuhaus P, Terrault N, Colombo M, et al. Adefovir dipivoxil for wait-listed and postliver transplantation patients with lamivudine-resistant hepatitis B: final long-term results. Liver Transpl 2007;13:349-60. doi: 10.1002/lt.20981.

59. Gane EJ, Patterson S, Strasser SI, McCaughan GW, Angus PW. Combination of lamivudine and adefovir without hepatitis B immune globulin is safe and effective prophylaxis against hepatitis B virus recurrence in hepatitis B surface antigen-positive liver transplant candidates. Liver Transpl 2013;19:268-74. doi: 10.1002/lt.23600.

60. Mehrabi A, Esmaeilzadeh M, Fonouni H, Hafezi M, Rahbari NN, Golriz M, et al. The role of HBIg as hepatitis B reinfection prophylaxis following liver transplantation. Langenbecks Arch Surg 2012;397:697-710. doi: 10.1007/s00423-011-0795-6.

61. Terrault NA, Zhou S, Combs C, Hahn JA, Lake JR, Roberts JP, et al. Prophylaxis in liver transplant recipients using a fixed dosing schedule of hepatitis B immunoglobulin. Hepatology 1996;24:1327-33. doi: 10.1002/hep.510240601.

62. Nymann T, Shokouh-Amiri MH, Vera SR, Riely CA, Alloway RR, Gaber AO. Prevention of hepatitis B recurrence with indefinite hepatitis B immune globulin (HBIG) prophylaxis after liver transplantation. Clin Transplant 1996;10:663-7.

63. Dindoost P, Jazayeri SM, Alavian SM. Hepatitis B immune globulin in liver transplantation prophylaxis: an update. Hepat Mon 2012;12:168-76. doi: 10.5812/hepatmon.832.

64. Avolio AW, Nure E, Pompili M, Barbarino R, Basso M, Caccamo L, et al. Liver transplantation for hepatitis B virus patients: long-term results of three therapeutic approaches. Transplant Proc 2008;40:1961-4. doi: 10.1016/j.transproceed.2008.05.071.

65. Bulbul A, Karadag A, Köklü E, Pamuk U, Sarici SU, Anaphylactic shock due to hepatitis B immunoglobulin in a newborn. J Matern Fetal Neonatal Med 2010;23:1257-9. doi: 10.3109/14767051003653260.

66. Ammann EM, Jones MP, Link BK, Carnahan RM, Winiecki SK, Torner JC, et al. Intravenous immune globulin and thromboembolic adverse events in patients with hematologic malignancy. Blood 2016;127:200-7. doi: 10.1182/ blood-2015-05-647552.

67. Perrillo R, Rakela J, Dienstag J, Levy G, Martin P, Wright $\mathrm{T}$, et al. Multicenter study of lamivudine therapy for hepatitis B after liver transplantation. Lamivudine Transplant Group. Hepatology 1999;29:1581-6. doi: 10.1002/hep.510290507.

68. Perrillo RP, Wright T, Rakela J, Levy G, Schiff E, Gish R, et al. A multicenter United States-Canadian trial to assess lamivudine monotherapy before and after liver transplantation for chronic hepatitis B. Hepatology 2001;33:424-32. doi: 10.1053/jhep.2001.21554.

69. Bárcena R, Del Campo S, Moraleda G, Casanovas T, Prieto M, Buti M, et al. Study on the efficacy and safety of adefovir dipivoxil treatment in post-liver transplant patients with hepatitis $B$ virus infection and lamivudine-resistant hepatitis B virus. Transplant Proc 2005;37:3960-2. doi: 10.1016/j. transproceed.2005.10.061.

70. Naoumov NV, Lopes AR, Burra P, Caccamo L, Iemmolo RM, de Man RA, et al. Randomized trial of lamivudine versus hepatitis B immunoglobulin for long-term prophylaxis of hepatitis B recurrence after liver transplantation. $J$ Hepatol 2001;34:888-94. doi: 10.1016/s0168-8278(01)00039-3.

71. Fung J. HBV therapeutic vaccines and cccDNA inhibitors - emergence of a cure. Liver transpl 2016;22:52-6. doi: 10.1002/lt.24617.

72. Johnson MA, Moore KH, Yuen GJ, Bye A, Pakes GE. Clinical Pharmacokinetics of lamivudine. Clin pharmacokinet 1999;36:41-66. doi: 10.2165/00003088-199936010-00004.

73. Dando T, Plosker G. Adefovir dipivoxil: a review of its use in chronic hepatitis B. Drugs 2003;63:2215-34. doi: 10.2165/00003495-200363200-00007.

74. Kearney BP, Yale K, Shah J, Zhong L, Flaherty JF. Pharmacokinetics and dosing recommendations of tenofovir disoproxil fumarate in hepatic or renal impairment. Clin Pharmacokinet 2006;45:1115-24. doi: 10.2165/00003088-200645110-00005.

75. Li W, Jia L, Zhao X, Wu X, Tang H. Efficacy and safety of tenofovir in preventing mother-to-infant transmission of hepatitis B virus: a meta-analysis based on 6 studies from China and 3 studies from other countries. BMC Gastroenterol 2018;18:121. doi: 10.1186/s12876-018-0847-2.

76. Dickson RC, Terrault NA, Ishitani M, Reddy KR, Sheiner P, Luketic V, et al. Protective antibody levels and dose requirements for IV 5\% Nabi Hepatitis B immune globulin combined with lamivudine in liver transplantation for hepatitis B-induced end stage liver disease. Liver Transpl 2006;12:124-33. doi: 10.1002/1t.20582.

77. Nath DS, Kalis A, Nelson S, Payne WD, Lake JR, Humar A. Hepatitis B prophylaxis post-liver transplant without maintenance hepatitis B immunoglobulin therapy. Clin Transplant 2006;20:206-10. doi: 10.1111/j.1399-0012.2005.00467.x.

78. Yi NJ, Choi JY, Suh KS, Cho JY, Baik M, Hong G, et al. Posttransplantation sequential entecavir monotherapy following 1-year combination therapy with hepatitis B immunoglobulin. J Gastroenterol 2013;48:1401-10. doi: 10.1007/s00535-0130761-x.

79. Yuefeng M, Weili F, Wenxiang T, Ligang X, Guiling L, Hongwei $\mathrm{G}$, et al. Long-term outcome of patients with lamivudine after early cessation of hepatitis B immunoglobulin for prevention of recurrent hepatitis B following liver transplantation. Clin Transplant 2011;25:517-22. doi: 10.1111/j.13990012.2010.01290.x.

80. Tanaka T, Renner EL, Selzner N, Therapondos G, Lilly LB. One year of hepatitis B immunoglobulin plus tenofovir therapy is safe and effective in preventing recurrent hepatitis B post-liver transplantation. Can J Gastroenterol Hepatol 2014;28:41-4. doi: 10.1155/2014/839014.

81. Nassiri-Toosi M, Kasraianfard A, Ahmadinejad Z, Dashti H, Moini M, Najafi A, et al. Efficacy and safety of lamivudine or tenofovir plus intramuscular hepatitis B immunoglobulin 
in prevention of hepatitis B virus reinfection after liver transplant. Exp Clin Transplant 2015;13:127-32.

82. Toosi MN, Jafarian A, Moini M, Najafi A, Ahmadinegad Z, Salimi M, et al. Low-Dose Hepatitis B Immune Globulin Combined With Lamivudine Is Successful For Prophylaxis Against Hepatitis B Recurrence After Orthotopic Liver Transplantation: 1256. Transplantation 2008;86:426. doi: 10.1097/01.tp.0000331548.26727.e0

83. Toosi M, Jafarian A, Razavi S, Moini M, Emami S, Ahmadinegad Z, et al. Report of success of lamivudine combined with intramuscular hepatitis B immune globulin for prophylaxis against hepatitis B recurrence after orthotopic liver transplantation. J Gastroenterol Hepatol 2004;19.

84. Milich DR. The Concept of Immune Tolerance in Chronic Hepatitis B Virus Infection Is Alive and Well. Gastroenterology 2016;151:801-4. doi: 10.1053/j.gastro.2016.09.037.

85. Lo CM, Liu CL, Chan SC, Lau GK, Fan ST. Failure of hepatitis $\mathrm{B}$ vaccination in patients receiving lamivudine prophylaxis after liver transplantation for chronic hepatitis B. J Hepatol 2005;43:283-7. doi: 10.1016/j.jhep.2005.03.013.

86. Bian Y, Zhang Z, Sun Z, Zhao J, Zhu D, Wang Y, et al. Vaccines targeting preS1 domain overcome immune tolerance in hepatitis B virus carrier mice. Hepatology 2017;66:1067-82. doi: 10.1002/hep.29239.

87. Yum JS, Ahn BC, Jo HJ, Kim DY, Kim KH, Kim HS, et al. Use of pre-S protein-containing hepatitis B virus surface antigens and a powerful adjuvant to develop an immune therapy for chronic hepatitis B virus infection. Clin Vaccine Immunol 2012;19:120-7. doi: 10.1128/CVI.05355-11.

88. Lo CM, Lau GK, Chan SC, Fan ST, Wong J. Efficacy of a pre-S containing vaccine in patients receiving lamivudine prophylaxis after liver transplantation for chronic hepatitis B. Am J Transplant 2007;7:434-9. doi: 10.1111/j.16006143.2006.01636.x.

89. Wang SH, Loh PY, Lin TL, Lin LM, Li WF, Lin YH, et al. Active immunization for prevention of De novo hepatitis B virus infection after adult living donor liver transplantation with a hepatitis B core antigen-positive graft. Liver Transpl 2017;23:1266-72. doi: 10.1002/lt.24814.

90. Lenci I, Tisone G, Di Paolo D, Marcuccilli F, Tariciotti L, Ciotti $\mathrm{M}$, et al. Safety of complete and sustained prophylaxis withdrawal in patients liver-transplanted for HBV-related cirrhosis at low risk of HBV recurrence. J Hepatol 2011;55:587-93. doi: 10.1016/j.jhep.2010.12.036.

91. Kasraianfard A, Watt KD, Lindberg L, Alexopoulos S, Rezaei N. HBIG Remains Significant in the Era of New Potent Nucleoside Analogues for Prophylaxis Against Hepatitis B Recurrence After Liver Transplantation. Int Rev immunol 2016;35:312-24. doi: 10.3109/08830185.2014.921160.

92. Cholongitas E, Papatheodoridis GV, Burroughs AK. Liver grafts from anti-hepatitis B core positive donors: a systematic review. J Hepatol 2010;52:272-9. doi: 10.1016/j.jhep.2009.11.009.

93. British Transplantation Society. Guidelines for Hepatitis B \&
Solid Organ Transplantation: British Transplantation Society 2018 . https://bts.org.uk/wp-content/uploads/2018/03/BTS HepB_Guidelines_FINAL_09.03.18.pdf(16 December 2020).

94. Naoumov NV, Lopes AR, Burra P, Caccamo L, Iemmolo RM, de Man RA, et al. Randomized trial of lamivudine versus hepatitis B immunoglobulin for long-term prophylaxis of hepatitis B recurrence after liver transplantation. $J$ Hepatol 2001;34:888-94. doi: 10.1016/s0168-8278(01)00039-3.

95. Kawagishi N, Takeda I, Miyagi S, Satoh K, Akamatsu Y, Sekiguchi S, et al. Nucleoside analogue therapy following one-year course of hepatitis B immunoglobulin in preventing hepatitis B virus reactivation after living donor liver transplantation. Tohoku J Exp Med 2010;222:275-9. doi: 10.1620/ tjem.222.275.

96. Yahyazadeh A, Beckebaum S, Cicinnati V, Klein C, Paul A, Pascher A, et al. Efficacy and safety of subcutaneous human HBV-immunoglobulin (Zutectra ${ }^{\circledR}$ ) in liver transplantation: an open, prospective, single-arm phase III study. Transpl Int 2011;24:441-50. doi: 10.1111/j.1432-2277.2011.01222.x. 